\title{
Scientists
}

\section{Curiosity and observation}

\author{
Huda Zoghbi
}

Ralph D. Feigin Professor, Departments of Pediatrics, Molecular and Human Genetics, Neurology, and Neuroscience, Baylor College of Medicine; Investigator, Howard Hughes Medical Institute; Director, Jan and Dan Duncan Neurological Research Institute at Texas Children's Hospital, Houston, TX

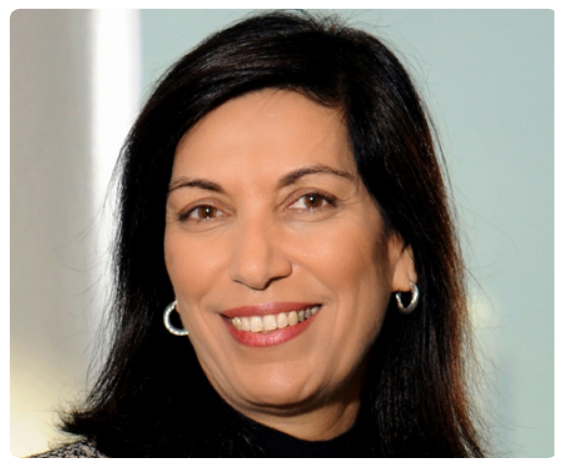

Huda Zoghbi's research on neurodevelopment and neurodegeneration caught our attention. Curious to know more, BioTechniques contacted her to find out about the ambitions, character, and motivations that led to her success.

I understand that you originally trained as a pediatric neurologist. What led you into the laboratory?

As a first-year resident in pediatric neurology in 1983, I came across an article by B. Hagberg on European patients with Rett syndrome, which was only barely described at the time. That same week, I encountered a patient in the clinic who fit Hagberg's description exactly. I was struck by her history. She did so well, speaking and moving just like a healthy two-year-old. Then by age three, she lost all those skills, became socially withdrawn, and lost the use of her hands. A week later, in a different clinic in our hospital, I chose to see a patient diagnosed with cerebral palsy. The minute the child walked into the room, I saw her wringing her hands, behaving exactly like the girl I saw the week before. Two girls with the same syndrome I only learned about a week ago, how could that be?

As a pediatric neurologist, I was accustomed to seeing children who never developed skills and children born normally whose skills degenerated. But this case wasn't degenerative; it was regressive. By the time I saw 10 more girls with Rett syndrome, I wanted to figure out what happened in a brain that started out normal, but regressed without degenerating. The only way I could do this was to clone the gene responsible for Rett syndrome. I was brought to the lab by an element of chance, curiosity, and observation.

\section{How did you begin hunting for the gene?}

The beautiful thing about youth is naivety. I didn't pause to think about the fact that cases of Rett syndrome are sporadic or that, when entering the lab in 1985, techniques for mapping genes were in their infancy. My mentor, Dr. Arthur Beaudet, advised me to work on a Mendelian disorder as a training project. We chose spinocerebellar ataxia type 1 (SCA1) and I began collecting families and mapping. I learned quickly that most results are negative, which was very difficult for me. I had to go to a different floor to develop my x-rays and I remember a couple of times stopping, sitting on the stairs, and crying. In all those early experiments, I never got close to the gene I was looking for. The beginning was awful.

It was a challenge resisting the urge to give it all up and go back to an easier life where I could be successful either as a faculty member in a medical school or in private practice. I wouldn't have to work late hours or always be faced with failure. A few tears helped cure me of that vulnerability, but what really stopped me from yielding was a K08 NIH fellowship I had with five years of funding. I told my husband, "I am going to give basic research my best for five years. No matter what happens, I will not give up before five years, and at the end, I will know if this is for me or not." That promise helped me endure a lot of frustration. In science, you can't judge your success on a day-to-day basis. You really need time before you start seeing the fruit of your investment. It took 16 years after my first encounter with Rett syndrome before I found the gene responsible.

\section{What has been the highlight of your career?}

The highlights of my life are my husband William and my two children. Similarly, one of the highlights of my career has been my collaboration with Harry Orr. This year marks our $25^{\text {th }}$ anniversary of collaborating together.
How did you establish such a long-term collaboration?

When I was looking for the SCA1 gene, HLA was the most polymorphic marker on chromosome 6, so I tried to map the SCA1 gene with respect to HLA. Based on the family I was studying, SCA1 mapped proximal to HLA, but Harry published a paper mapping the gene for SCA1 distal to HLA. At the time, the chance that there might be two loci for such a rare disease on either side of HLA didn't seem feasible; this really bothered me.

One day I was staring at the pedigree. I had five generations and everyone who was affected was a blood-line relative. One affected woman was dead, so I never examined her. Her mother had the disease and her three daughters had the disease. If I removed these three daughters from the pedigree, my gene mapped exactly where Harry's gene did. I drove back to Montgomery, TX and asked the daughters to tell me about their mother. After hearing their descriptions, I thought that she might have had a stroke rather than SCA1. So I asked about their father. He died at age 40 when he was hit by a car while crossing the street. I wondered if these three girls actually inherited SCA1 from their unrelated father.

It's almost impossible that someone with a disease with a $1 / 100,000$ prevalence would marry into the family, but I decided to use that model for additional analyses. In this case, the gene mapped right on top of Harry's gene. The family came from a small town, so it's conceivable that he was related many generations before. I picked up the phone, called Harry, told him my story, and said I think we are working on the same gene. Then I simply asked him to collaborate. Caught off guard, Harry paused for 30 seconds or so to think, but finally agreed. From that moment on, we have worked together. We discovered the SCA1 gene on the same day.

Interviewed by Kristie Nybo, Ph.D. Image courtesy of Agapito Sanchez. [IGA

BioTechniques 55: 53 (August 2013)

doi 10.2144/000114060 